\title{
Fauna of Protected Areas - 21 \\ AMPHIBIAN FAUNA OF KERALA: COMMUNITY STRUCTURE
}

\author{
M.I. Andrews ${ }^{1}$, Sanil George ${ }^{2}$ and Jaimon Joseph ${ }^{3}$ \\ 1,3 Department of Zoology, Mar Thoma College, Tiruvalla, Kerala 689103, India \\ ${ }^{2}$ RGCB, Trivandrum, Kerala 695014, India \\ Email: ${ }^{1}$ mipeandrews@yahoo.co.in; 2 rhacophorus@rediffmail.com
}

Abstract

Diversity, evenness, richness, ecological distribution, niche breadth and niche overlap of amphibian assemblages in the protected areas of Kerala were determined. The amphibian assemblages studied in all the protected areas showed high diversity in composition and distribution of species. The study of species distribution indicates the presence of highly organised natural communities. The amphibian communities at these areas show greater ecological similarity among coexisting species. The amphibian assemblage was composed of some abundant species together with rare specialists. This pattern indicates that the protected areas are undergoing natural succession towards accommodating rare species along with the common species by gradually occupying the niche hyperspace available.

\section{KeYwORDS \\ Amphibians, community structure, protected areas, Kerala}

Recently much importance is being given to the conservation of amphibians and the manner in which amphibian communities function. Organization of communites of frogs in Sarawak has been reported (Inger \& Greenberg, 1966; Inger, 1969). Crump (1971) made a quantitative analysis of ecological distribution of a tropical herpetofauna. Inger and Colwell (1977) studied the organization of contiguous communities of amphibians and reptiles in Thailand. Densities of floor dwelling frogs in lowland forests of south-west Asia and central America have been investigated by Inger (1980). Inger and Vories (1993) have carried out a comparative study on the Bornean amphibian communities. However, very little work has been done on the community structure of amphibians of India (Dash \& Mahanta, 1993; Das, 1996; Vasudevan et al., 2001).

Though Kerala has a rich amphibian fauna, no detailed study has been done on their community structure except the work done by Inger et al. (1987) and Andrews et al. (2005a,b). Hence, the present study on the community structure of amphibians was carried out in all the protected areas in Kerala part of the Western Ghats.

\section{Methodology}

The study was carried out from August 1999 to August 2002. The methodology adopted in the present study is strictly in accordance with the standard methods formulated for measuring and monitoring the amphibian diversity by IUCN/SSC- DAPTF (Heyer et al., 1994; see Andrews et al., 2005a,b). The characteristic features of all the protected areas in Kerala and their amphibian fauna were presented in Andrews et al. (2005). For studying the community structure of amphibian assemblages at these sites, each study site was divided into suitable quadrats; $50 \mathrm{~m} \times 50 \mathrm{~m}$ quadrats ( 2 to 8 at all sites) were demarcated on the selected forest floor and searched thoroughly in such a way so that the escape of amphibians from the area was almost impossible. At all sites searching of amphibians was done from one end to another of each quadrat at a stretch during which logs were ripped apart and rolled, rocks turned, litter raked and vegetation examined. Sampling in each quadrat was done for six hours daily ( 0600 to $0900 \mathrm{hr}$ and 1700 to $2000 \mathrm{hr}$ ) for a period of 1-2 weeks, depending upon the area of study site by two persons using collecting nets and large torches. Amphibians captured were identified, measured and released as per the standard methods for amphibians (Heyer et al., 1994). Specimens obtained only from the quadrats were used for the community structure analysis. Diversity, evenness, richness, ecological distribution, niche breadth and niche overlap of amphibians at all the sites have been determined using the formulae given below. All the calculations were done with the software ecological methodology (Krebs, 1999).

1. Simpson's index of diversity:

$$
I-D=I-\sum\left(P_{I}\right)^{2}
$$

$\mathrm{I}-\mathrm{D}=$ Simpson's index of diversity $; \mathrm{P}_{\mathrm{i}}=$ Proportion of individuals of species ' $\mathrm{i}$ ' in the community.

2. Shannon- Weiner diversity:

$$
H^{\prime}=\sum_{i=1}^{S}\left(P_{i}\right)\left(\log 2 P_{i}\right)
$$

$\mathrm{H}^{\prime}=$ Index of species diversity; $\mathrm{s}=$ Number of species; $\mathrm{P}_{\mathrm{i}}=$ Proportion of total sample belonging to $\mathrm{i}^{\text {th }}$ species.

3. Brillouin's diversity :

$$
\hat{H}=\frac{1}{N} \log \left(\frac{N !}{n_{1} ! n_{2} ! n_{3} ! \ldots \ldots}\right)
$$

$\hat{H}=$ Brillouin's diversity; $\mathrm{N}=$ Total number of individuals in entire collection; $\mathrm{n}_{1}$ ! = Number of individuals belonging to species $1 ; \mathrm{n}_{2}$ ! = Number of individuals belonging to species 2; $\mathrm{n}_{3}$ ! = Number of individuals belonging to species 3 .

Since this is part of a series, refer to Andrews et al., 2004, 2005 for more details and also refer the web supplements at www.zoosprint.org for photographs of frogs studied. 
4. Smith and Wilson's measure of evenness :

$$
\underset{\mathrm{var}}{E}=1-\left[\frac{2}{\pi \arctan \left\{\sum_{i=1}^{S}\left(\log _{e}\left(n_{i}\right)-\sum_{j=1}^{S} \log _{e}\left(n_{j}\right) / s\right)^{2} / S\right\}}\right]
$$

$\underset{\mathrm{var}}{E}=$ Smith and Wilson's index of evenness; $\mathrm{n}_{\mathrm{i}}=$ Number of individuals in species $i$ in sample $(i=1,2,3 \ldots) ; n_{j}=$ Number of individuals in species $\mathrm{j}$ in sample $(\mathrm{j}=1,2,3 \ldots) ; \mathrm{S}=$ Number of species in entire collection.

5. Jackknife estimate of species richness:

$$
S^{\prime}=s+\left(\frac{n-1}{n}\right) k
$$

$\mathrm{S}$ '= Jackknife's estimate of species richness; $\mathrm{s}=$ Observed total number of species present in $n$ quadrat; $n=$ Total number of quadrat samples; $\mathrm{k}=$ Number of unique species.

6. Levins's measure of niche breadth:

$$
B=\frac{y^{2}}{\sum N j^{2}}
$$

$B=$ Levins's measure of niche breadth; $N_{j}=$ Number of individuals found in or using resource state $\mathrm{j} ; \mathrm{Y}=$ Total number of individuals sampled.

7. Horn's index of niche overlap:

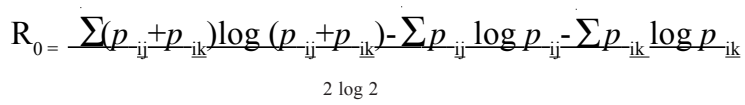

$\mathrm{R}_{0}=$ Horn's Index; $\mathrm{P}_{\mathrm{ij}}=$ Proportion resource $\mathrm{i}$ is of the total resources utilized by species $\mathrm{j} ; \mathrm{P}_{\mathrm{ik}}=$ Proportion resource $\mathrm{i}$ is of the total resources utilized by species $\mathrm{k}$

\section{Results}

The community structure of amphibian assemblages in the protected areas of Kerala is as follows:

\section{Agasthyavanam Biological Park}

Agasthyavanam Biological Park was found to be rich in amphibian diversity. Rana temporalis alone contributed $41.46 \%$ of the total diversity of this region with an evenness index of 0.761 . Species richness was found to be 6.3 with five unique species (Table 1). The resource states based on microhabitat preference were divided into six subgroups such as in water, on grass, on bare soil, on shrubs, on sand and on rocks. The distribution of amphibians was 5 individuals $/ 2$ species in water, $3 / 1$ on grass, $5 / 3$ on bare soil, $3 / 3$ on rocks, $1 / 1$ on sand and $4 /$ 1 on shrubs. Levins's standardized niche breadth was 0.740 with five frequently used resource states (Table 1).
Total overlap (100\%) was not found between any of the five species recorded from Agasthyavanam. Maximum overlap was found between Fejervarya keralensis and Bufo melanostictus (Table 2). Here Rana temporalis, Fejervarya keralensis and Nyctibatrachus major were found to be sharing the microhabitats with three other species followed by Bufo melanostictus with two species and Micrixalus fuscus with one species.

\section{Aralam Wildlife Sanctuary}

Out of the 25 species reported from Aralam WLS, 11 species were obtained from the quadrat study. Simpson's, ShannonWeiner's and Brillouin's indices (Table 1) indicate a high diversity. Rana temporalis and Indirana beddomii contributed $52.3 \%$ of the total diversity. The distribution of amphibian community at Aralam WLS was not found to be even. Estimated species richness of the 11 species recorded from the sanctuary was found to be 13.7 with four unique species such as Philautus beddomii, Fejervarya brevipalmata, Micrixalus nudis and Philautus pulcherrimus. The ecological distribution of amphibians was 18 individuals/2 species on leaf litter; 14/2 on rocks; $7 / 3$ on logs; $13 / 3$ on wet soil, $12 / 1$ under water; $13 / 1$ on water surface; $22 / 3$ under stones; $10 / 4$ on streams banks; $4 / 1$ on stream floor; $2 / 2$ on grass; $5 / 1$ on boulders and $6 / 2$ on shrubs. Levins's standardized niche breadth score was found to be 0.750 (Table 1) with eight frequently used resource states out of 12 resource states identified from the area.

Horn's index (Table 2) indicated that Philautus beddomii and P. pulcherrimus showed $100 \%$ overlap. Nyctibatrachus major has no overlap with any of the 10 species recorded from Aralam. Of the 11 species, Fejervarya keralensis (habitat generalist) was found to be sharing the microhabitat with six other species with varying degrees of overlap such as with Philautus leucorhinus (0.288), Indirana beddomii (0.172), Rana temporalis (0.710), Euphlyctis cyanophlyctis (0.131), Micrixalus saxicolus (0.230) and $M$. nudis (0.390). This was followed by $P$. leucorhinus with five species and $R$. temporalis with four species.

\section{Chimmini Wildlife Sanctuary}

Amphibian diversity at Chimmini WLS was found to be rich as evidenced from the diversity indices used in the present study (Table 1). Fejervarya keralensis, Euphlyctis cyanophlyctis and Bufo melanostictus contributed $66.7 \%$ of the total amphibian diversity with an even distribution as indicated by the evenness measure. Species richness was found to be 6.5. The ecological distribution of amphibians was 8 individuals/ 1 species on bare soil; $13 / 2$ in water; $9 / 3$ on wet sand; $10 / 2$ on leaf litter; $2 / 1$ on boulders; $3 / 1$ on bushes. Levins's standardized niche breadth was 0.748 with five frequently used resource states out of six resource states identified from the study area (Table 1).

Horn's Index (Table 2) revealed the absence of $100 \%$ overlap of microhabitats by individual species in Chimmini. Zero percent overlap of microhabitats was exhibited by Bufo melanostictus and Philautus leucorhinus. Fejervarya keralensis shared the microhabitat with three other species reported from the area. 


\section{Chinnar Wildlife Sanctuary}

All the eight species recorded from the Chinnar WLS were obtained from the quadrat study. Fejervarya keralensis, Rana temporalis and Bufo melanostictus contributed $76.2 \%$ of the total amphibian diversity in Chinnar. Simpson's diversity was found to be 0.755 , which indicates a high diversity. ShannonWeiner and Brillouin's diversity also showed the same pattern (Table 1). Based on the evenness measure, the distribution of amphibians in the sanctuary was not found to be even. Estimated species richness was 8.7 (Table 1). One species was found to be unique in the area. The resource states based on microhabitat preferences were divided into nine subgroups. The distribution of amphibians within the quadrats was found as 15 individuals/2 species in bare soil; $2 / 1$ under boulders; $45 /$ 2 on wet soil; $10 / 2$ on rocks in streams; $9 / 2$ on leaf litter; $3 / 1$ on water plants; $3 / 3$ on shrubs; $18 / 2$ in water (submerged) and $17 /$ 4 in decayed leaf litter. Levins's standardized niche breadth score was 0.482 (Table 1). Six frequently used resource states out of nine were identified. It was found that Nyctibatrachus major and N. minor showed $100 \%$ overlap (Table 2).

\section{Eravikulam National Park}

Amphibian diversity of Eravikulam National Park was found to be impressive as indicated by the diversity indices (Table 1). Fejervarya nilagirica, Bufo parietalis and Rana temporalis contributed $76.6 \%$ of the total diversity of this National Park with an even distribution as indicated by the evenness measure. Species richness was found to be 8.5 with three unique species, viz., Indirana leptodactylus, Philautus femoralis and $P$. signatus (Table 1). The ecological distribution of amphibians revealed from the quadrat study was 13 individuals/4 species on leaf litter; $5 / 2$ on wet soil; $6 / 1$ on grass; $1 / 1$ on wet rocks; $3 /$ 1 in water and $2 / 2$ on herbs. Levins's standardized niche breadth was found as 0.538 with five frequently used resource states out of six resource states identified from the Park (Table 1).

Horn's Index indicates that Bufo parietalis / Indirana leptodactylus and Philautus femoralis / P. signatus show 100\% overlap of microhabitats at Eravikulam. Nyctibatrachus major was not seen to be associated with any of the species $(0 \%$ overlap). Bufo parietalis, Fejervarya nilagirica, Indirana leptodactylus and Rana temporalis were habitat generalists since they shared their microhabitats with three other species (Table 2).

\section{Idukki Wildlife Sanctuary}

Out of the eight species reported from the Sanctuary, five species were recorded from the quadrat study. Diversity indices showed that the amphibian diversity was low. Here Fejervarya keralensis alone contributed $51.5 \%$ of the total diversity followed by Indirana beddomii and the distribution of amphibians was seen to be even as indicated by the evenness measure. Estimated species richness was found to be six with two unique species, viz. Philautus leucorhinus and Micrixalus nudis (Table 1). The ecological distribution of amphibians at this sanctuary was 6 individuals/ 1 species in water; $5 / 2$ on bare soil; $3 / 1$ under stone; $14 / 2$ on leaf litter; $2 / 2$ on wet rock; $3 / 1$ on herbs and shrubs. Levins's standardised niche breadth score was 0.468 with four frequently used resources states out of six resource states reported from the study area.

Horn's Index indicated the absence of $100 \%$ overlap of microhabitats by any of the species reported from Idukki WLS. However, Fejervarya keralensis was found to be sharing its habitat with Indirana beddomii and Micrixalus nudis while Indirana beddomii with Fejervarya keralensis and Bufo melanostictus. P. leucorhinus did not share its habitat with any other species reported from the area ( $0 \%$ overlap; Table 2$)$.

\section{Neyyar Wildlife Sanctuary}

Amphibian diversity at Neyyar WLS was found to be rich as evidenced from the diversity indices. Fejervarya keralensis and Bufo melanostictus together contributed $54.8 \%$ of the total amphibian diversity of the area with an even distribution as indicated by the evenness measure (Table 1). Species richness was found to be 11.7 with one unique species, Nyctibatrachus major. The ecological distribution of amphibians was 14 individuals/2 species on bare soil; 8/1 under stone; 19/4 on leaf litter; $3 / 2$ in marsh; $5 / 2$ on grass; $7 / 5$ in water; $1 / 1$ on logs; $8 / 2$ in wet crevices; $6 / 3$ in wet soil and $2 / 1$ on herbs. Levins's standardized niche breadth was found to be 0.621 (Table 1) with seven frequently used resource states out of 10 resource states identified from the sanctuary.

Total overlap (100\%) of the microhabitats was not exhibited by any of the species recorded from the sanctuary (Table 2). Philautus leucorhinus exhibited $0 \%$ overlap. Micrixalus fuscus, Fejervarya keralensis and Fejervarya limnocharis were habitat generalists in the Neyyar since they shared their microhabitats with four species, followed by Bufo melanostictus, Indirana beddomii, Euphlyctis cyanophlyctis, Euphlyctis hexadactylus and Nyctibatrachus major with three species each.

\section{Parambikulam Wildlife Sanctuary}

R. temporalis and Fejervarya keralensis contributed $45.7 \%$ of the total diversity of amphibians with an evenness score of 0.737. Species richness was found to be 10.5 with three unique species such as Bufo melanostictus, Nyctibatrachus major and Philautus leucorhinus (Table 1). The ecological distribution of amphibians at Parambikulam WLS was 1 individual belonging to 1 species on herbs; $9 / 3$ on leaf litter; $7 / 4$ on bare soil; $5 / 2$ in water; $4 / 2$ on grass; $2 / 1$ on wet soil; $1 / 1$ on logs; $2 / 1$ as rocks and $4 / 1$ under stones.

Euphlyctis cyanophlyctis and Nyctibatrachus major showed $100 \%$ overlap of their microhabitats (Horn's Index). Philautus leucorhinus showed no overlap. Fejervarya keralensis can be considered as the habitat generalist since it shared its microhabitat with five other species, followed by Rana temporalis with four species (Table 2).

\section{Peechi-Vazhani Wildlife Sanctuary}

Amphibian diversity at Peechi-Vazhani WLS was found to be rich as evidenced from the diversity indices. Euphlyctis cyanophlyctis, Fejervarya nilagirica, Rana temporalis and Fejervarya keralensis contributed $61.4 \%$ of the total amphibian diversity with an even distribution. Species richness was found 
to be 9.5 with one unique species, Hoplobatrachus tigerinus. The ecological distribution of amphibians was 4 individuals belonging to 3 species on bare soil; $8 / 4$ on stream banks, $6 / 2$ in marshes, $8 / 1$ on water surface, $9 / 3$ in water; $4 / 1$ on herbs, $7 / 3$ on wet soil; 5/3 on leaf litter, 4/2 under stones and 10/4 in wet crevices. Levins's standardized niche breadth was found as 0.894 with 10 frequently used resource states (Table 1).

Horn's Index (Table 2) revealed the absence of $100 \%$ and $0 \%$ overlaps of microhabitats. Fejervarya nilagirica seemed to be the habitat generalist since it shared the microhabitat with six other species, followed by Rana temporalis, Fejervarya keralensis and Indirana beddomii with five species each.

\section{Peppara Wildlife Sanctuary}

Amphibian diversity of Peppara WLS was found to be rich as evidenced from the diversity indices. Rana temporalis alone contributed $44 \%$ of the total diversity of this region with an evenness index of 0.436 . Species richness was found to be 16.2 with five unique species (Table 1). The resource states based on microhabitat preference were divided into eight subgroups such as in water, on bare soil, on dead leaves, on rocks, on logs, on herbs, on shrubs and on trees. The distribution of amphibians was 38 individuals / 6 species in water; $20 / 6$ on bare soil; $7 / 3$ on dead leaves; $1 / 1$ on rocks; $2 / 1$ on logs; $28 / 2$ on herbs; $23 / 3$ on shrubs and $5 / 3$ on trees. Levins's standardised niche breadth was 0.535 with five frequently used resource states (Table 1).

In this Wildlife Sanctuary, Euphlyctis hexadactylus / E. cyanophlyctis and Rhacophorus malabaricus / Philautus pulcherrimus showed $100 \%$ overlap, which indicated that they were found together more often than other species in the area (Table 2). Among the total of 11 species recorded, Rana temporalis was found to be sharing the microhabitat with nine other species with varying degrees of overlap; this was followed by Fejervarya keralensis and Nyctibatrachus minor with seven species each. Philautus pulcherrimus, Polypedates pseudocruciger and Rhacophorus malabaricus were found to be the least associated species since their association for the microhabitats was limited to two species only.

\section{Periyar Tiger Reserve}

Rana temporalis alone contributed $40.7 \%$ of the total diversity of this region with an evenness index of 0.560 . Species richness was found to be 16.4 with five unique species. At this Tiger Reserve, the resource states were divided into five subgroups such as in water, on grass, on bare soil, on dead leaves and on rocks. The amphibians were distributed as 19 individuals/4 species in water, $66 / 7$ on grass, $27 / 6$ on bare soil, $32 / 4$ on dead leaves and $5 / 2$ on rocks. Levins's standardised niche breadth was 0.565 with four frequently used resource states.

At Periyar TR, Rana curtipes / Fejervarya limnocharis and Euphlyctis cyanophlyctis / Nyctibatrachus major were found to be more associated (Table 2). Here Rana temporalis was found to be sharing the microhabitat with all other species with varying degrees of overlap, followed by Fejervarya nilagirica,
Microhyla ornata and Bufo melanostictus with eight species each. Micrixalus fuscus was the least associated species as its association for the microhabitat was limited to one species only.

\section{Shenduruni Wildlife Sanctuary}

Fejervarya keralensis alone contributed $50 \%$ of the total diversity of Shenduruni with an evenness index of 0.676 ; species richness was 7.5 with three unique species -- Euphlyctis hexadactylus, Hoplobatrachus tigerinus and Fejervarya limnocharis. The ecological distribution of amphibians was 5 individuals $/ 2$ species on bare soil; $1 / 1$ on water surface; $4 / 3$ in water; $5 / 2$ on leaf litter; $2 / 2$ in wet soil and $1 / 1$ on grass. Levins's standardised niche breadth was 0.448 with six frequently used resource states (Table 1).

Total overlap (100\%) of the microhabitats was not exhibited by any of the species recorded from this Sanctuary (Horn's Index). Fejervarya limnocharis showed no overlap $(\mathrm{O} \%) ; F$. keralensis shared its microhabitat with four other species (Table 2).

\section{Silent Valley National Park}

Diversity index showed a tendency towards rich amphibian diversity at Silent Valley National Park (Table 1). Bufo parietalis and Rana temporalis contributed $53.6 \%$ of the total amphibian diversity of this region with an evenness index of 0.560 . Species richness was found to be 8.5 with three unique species such as Philautus nasutus, Nyctibatrachus aliciae and Philautus signatus. The ecological distribution of amphibians at the park was 1 individual/one species on leaf; $1 / 1$ on shrubs; $6 / 2$ in water; $3 / 2$ under stones; $6 / 2$ on leaf litter; $2 / 1$ under logs; $8 / 2$ on bare soil and $1 / 1$ on stream banks. Levins's standardized niche breadth was found to be 0.594 with five frequently used resource states out of eight identified in Silent Valley (Table 1).

Nyctibatrachus major and N. aliciae showed $100 \%$ overlap at this park (Horn's Index). No overlapping was exhibited by Philautus nasutus and $P$. signatus. Rana temporalis associated with two species with varying degrees of overlap (Table 2).

\section{Thattekkad Bird Sanctuary}

Out of the 16 species reported from Thattekkad BS, 11 species were obtained from the quadrat study. High diversity recorded in this Sanctuary was indicated by the diversity indices used in the present study. Rana temporalis and Indirana beddomii contributed $40.8 \%$ of the total diversity of the area. The distribution of the amphibians was found to be even as evidenced from the Smith and Wilson measure. Species richness was found to be 11.7 with one unique species, Indirana semipalmatus (Table 1). The ecological distribution of amphibians at Thattekkad BS was 3 individuals/1 species under stones; $8 / 2$ on bare soil; $12 / 4$ on wet soil; $21 / 4$ on leaf litter; 11/ 3 in marshes; $6 / 2$ on herbs and shrubs and $15 / 5$ in water. Levins's standardised niche breadth was found to be 0.759 with six frequently used resource states out of seven resource states identified from the study area (Table 1).

Horn's Index (Table 2) showed that Hoplobatrachus tigerinus and Euphlyctis cyanophlyctis exhibited $100 \%$ overlap of their 
microhabitats. Rana temporalis and Fejervarya limnocharis were the habitat generalists since they shared the microhabitats with eight other species with varying degrees of overlapping, followed by Fejervarya keralensis with seven other species. Bufo melanostictus was the least associated species since it shared its microhabitat with only Rana temporalis.

\section{Wayanad Wildlife Sanctuary}

Out of the 20 species reported from Wayanad WLS, 15 species were recorded from the quadrats. All three diversity indices showed a high diversity of amphibians in Wayanad. Rana curtipes, Rana temporalis and Euphlyctis hexadactylus contributed $51.2 \%$ of the total diversity index. Distribution of the amphibians was not found to be even. Estimated species richness was found to be 18.3 (Table 1). The ecological distribution of amphibians in Wayanad was: 26 individuals/4 species on river banks; $43 / 5$ in water; $34 / 5$ in leaf litter; $22 / 3$ under stones; $33 / 2$ on dry soil; $15 / 4$ on wet grass; $33 / 6$ on marshy area; $3 / 2$ on wet soil; $1 / 1$ on rocks; $1 / 1$ under logs; $3 / 2$ under soil; $14 / 2$ on herbs; $4 / 1$ on shrubs. Levins's standardized niche breadth score was found to be 0.576 with eight frequently used resource states out of 13 resource states identified from the sanctuary (Table 1).

Horn's index (Table 2) indicated that Icthyophis beddomii and Uraeotyphlus narayani showed 100\% overlap at Wayanad. Kaloula taprobanica and Rhacophorus malabaricus were the species restricted to their own microhabitats as they were not found to be sharing their microhabitats with any of the other reported species from the study area. Hoplobatrachus tigerinus can be considered as a habitat generalist as it shared its microhabitat with eight other species with varying degrees of overlap. This was followed by Euphlyctis hexadactylus with seven species. Rana curtipes and $R$. temporalis came next by associating with six other species each in the study area.

\section{Discussion}

The analysis of dominance, diversity and evenness indices provide valuable quantitative information about animal communities in different habitats. For the analysis of dominance, three indices were used in the present study, i.e., Simpson's diversity, Shannon-Weiner diversity and Brillouin's diversity. The range of Simpson's diversity (1-D) is $0-1$ and a value reaching 1 is indicative of very high diversity. ShannonWeiner diversity does not seem to exceed 5.0 for most of the biological communities since it ranges from 0 to 5 . Brillouin's index is used when the sampling is done without replacement. It is practically identical to Shannon-Weiner index. In the present study, amphibians distributed in all the Wildlife Sanctuaries/ National Parks showed high diversity. Simpson's diversity index showed that species diversity was found to be high in PechiVazhani WLS, followed by Thattekkad BS. However, ShannonWeiner diversity and Brillouin's index showed that amphibian diversity was high in Wayanad WLS, followed by Thattekkad BS. Idukki WLS showed the lowest diversity values according to the three indices. Distribution of amphibians in all the protected areas was found to be even with high evenness value recorded at Peechi-Vazhani WLS and the lowest value recorded at Aralam WLS.

Biological species richness was found to be very high in Wayanad WLS, followed by Periyar TR and Peppara WLS. Lowest value was obtained from the Idukki WLS. The amphibian assemblages studied in all the protected areas showed high diversity in composition and distribution of species, stressing the high conservation value of each site within Kerala. The amphibian assemblage present was composed of some abundant species together with the rarer specialists. This pattern suggests that these protected areas are undergoing a natural succession towards accommodating the rarer species along with the common species by gradually occupying the niche hyperspace available. This also indicates the existence of high environmental quality in these areas since amphibian communities require specific microhabitats to survive and reproduce (Hager, 1998). Frogs have permeable skin and are sensitive to environmental degradation in both terrestrial and aquatic habitats (Pearman, 1997). Frogs occupy high trophic levels in the food chain and, therefore, are sensitive to a broad range of environmental stress agents that disrupt lower trophic levels (Zug, 1993). For these reasons, amphibians are potentially excellent target species for monitoring fragmented or degraded areas (Raxworthy \& Attuquayefio, 2000). However, due to the lack of earlier studies in these protected areas, we have no idea regarding the decline/ abundance of amphibian communities through time and space. We strongly advocate that data on diversity and species richness pattern obtained in the present study be used as a baseline data for launching a long term study on the analysis of species abundance pattern in order to plan the conservation management of these protected areas.

Niche breadth measurement is used to find out how organisms utilize their environment. It is measured by observing the distribution of individual organisms within a set of resource states, i.e., microhabitats. The niche breadth refers to the habitat niche breadth. The species that utilize a broad spectrum of the environment are considered habitat generalists. The area having high niche breadth scores contains more habitat generalists. Species, which are apparently restricted in their distribution, live in a narrow range of the environmental spectrum and have low niche breadth score, are considered as habitat specialists. All other species can be considered as habitat intermediaries. In the present study, highest niche breadth score was obtained for the Peechi-Vazhani WLS, which harboured all the common amphibian species, the habitat generalists. This was followed by Agasthyavanam BP. The lowest niche breadth score was obtained for the amphibians at Shenduruni WLS, which does not reflect that amphibians at Shenduruni are habitat specialists. The niche breadth score obtained for Shenduruni WLS was 0.448 which indicates the presence of habitat intermediaries as the range for Levins's standardised niche breadth score is $0-1$. From this data we can assume that in Kerala, habitat specialists are practically nil for amphibians. Wide niche breadth can be correlated to the wide habitat requirements and tolerance to environmental gradients. The climate and topography of these areas do not vary much, and therefore no extreme conditions 
Table 1. Estimation of species diversity, evenness, richness and niche breadth of amphibian populations at different protected areas of Kerala

\begin{tabular}{|c|c|c|c|c|c|c|c|c|c|c|c|c|c|c|c|}
\hline & $\begin{array}{l}\text { Agast } \\
\text { BP }\end{array}$ & $\begin{array}{l}\text { Arala } \\
\text { WLS }\end{array}$ & $\begin{array}{l}\text { Chimm } \\
\text { WLS }\end{array}$ & $\begin{array}{l}\text { Chinn } \\
\text { WLS }\end{array}$ & $\begin{array}{l}\text { Eravi } \\
\text { NP }\end{array}$ & $\begin{array}{l}\text { Idukk } \\
\text { WLS }\end{array}$ & $\begin{array}{l}\text { Neyya } \\
\text { WLS }\end{array}$ & $\begin{array}{l}\text { Param } \\
\text { WLS }\end{array}$ & $\begin{array}{l}\text { Peech } \\
\text { WLS }\end{array}$ & $\begin{array}{l}\text { Peppa } \\
\text { WLS }\end{array}$ & $\begin{array}{l}\text { Periy } \\
\text { TR }\end{array}$ & $\begin{array}{l}\text { Shend } \\
\text { WLS }\end{array}$ & $\begin{array}{l}\text { Silen } \\
\text { NP }\end{array}$ & $\begin{array}{l}\text { Thatt } \\
\text { BS }\end{array}$ & $\begin{array}{l}\text { Wayan } \\
\text { WLS }\end{array}$ \\
\hline \multicolumn{16}{|l|}{ Diversity measures } \\
\hline Simpson's diversity (1-D) & 0.751 & 0.818 & 0.822 & 0.755 & 0.811 & 0.672 & 0.830 & 0.867 & 0.886 & 0.763 & 0.792 & 0.732 & 0.817 & 0.872 & 0.883 \\
\hline $\begin{array}{l}\text { Shannon-Weiner's } \\
\text { diversity }\left(\mathrm{H}^{\prime}\right)\end{array}$ & 2.064 & 2.750 & 2.448 & 2.328 & 2.421 & 1.825 & 2.867 & 2.885 & 3.058 & 2.665 & 2.830 & 2.099 & 2.419 & 3.127 & 3.404 \\
\hline Brillouin's diversity $(\mathrm{H})$ & 1.765 & 2.560 & 2.175 & 2.177 & 2.035 & 1.573 & 2.562 & 2.431 & 2.749 & 2.445 & 2.637 & 1.636 & 2.019 & 2.816 & 3.227 \\
\hline \multicolumn{16}{|l|}{ Evenness measure } \\
\hline $\begin{array}{l}\text { Smith and Wilson even } \\
\text { measure }\end{array}$ & 0.761 & 0.314 & 0.847 & 0.434 & 0.592 & 0.531 & 0.568 & 0.737 & 0.883 & 0.436 & 0.560 & 0.676 & 0.560 & 0.637 & 0.415 \\
\hline \multicolumn{16}{|l|}{ Species richness } \\
\hline Jackknife method & 6.3 & 13.7 & 6.5 & 8.7 & 8.5 & 6.0 & 11.7 & 10.5 & 9.5 & 16.2 & 16.4 & 7.5 & 8.5 & 11.7 & 18.3 \\
\hline \multicolumn{16}{|l|}{ Niche breadth } \\
\hline $\begin{array}{l}\text { Levins's standardised } \\
\text { niche breadth }\end{array}$ & 0.740 & 0.750 & 0.748 & 0.482 & 0.538 & 0.468 & 0.621 & 0.644 & 0.894 & 0.535 & 0.565 & 0.448 & 0.594 & 0.759 & 0.576 \\
\hline No. of resource states & 6 & 12 & 6 & 9 & 6 & 5 & 10 & 9 & 10 & 8 & 5 & 6 & 8 & 7 & 13 \\
\hline $\begin{array}{l}\text { No. of frequently used } \\
\text { resource states }\end{array}$ & 5 & 8 & 5 & 6 & 5 & 4 & 7 & 6 & 10 & 5 & 4 & 6 & 5 & 6 & 8 \\
\hline
\end{tabular}

Table 2. Summary of the niche overlap of amphibians at different protected areas in Kerala (based on Horn's Index)

\begin{tabular}{|c|c|c|c|}
\hline Sanctuary/National Park & Species having $100 \%$ overlap & Species having $0 \%$ overlap & Habitat generalists \\
\hline Agasthyavanam BP & -- & -- & $\begin{array}{l}\text { Rana temporalis, Fejervarya } \\
\text { keralensis, Nyctibatrachus major }\end{array}$ \\
\hline Aralam WLS & Philautus beddomei/ P. pulcherrimus & Nyctibatrachus major & Fejervarya keralensis \\
\hline Chimmini WLS & -- & $\begin{array}{l}\text { Bufo melanostictus / } \\
\text { Philautus leucorhinus }\end{array}$ & Fejervarya keralensis \\
\hline Chinnar WLS & Nyctibatrachus major / N.minor & -- & -- \\
\hline Eravikulam NP & $\begin{array}{l}\text { Bufo parietalis / Indirana leptodactylus; } \\
\text { Philautus femoralis / P. signatus }\end{array}$ & Nyctibatrachus major & $\begin{array}{l}\text { Bufo parietalis, Fejervarya } \\
\text { nilagirica, Indirana leptodactylus, } \\
\text { Rana temporalis }\end{array}$ \\
\hline Idukki WLS & -- & Philautus leucorhinus & $\begin{array}{l}\text { Fejervarya keralensis, Indirana } \\
\text { beddomii }\end{array}$ \\
\hline Neyyar WLS & -- & Philautus leucorhinus & $\begin{array}{l}\text { Micrixalus fuscus, Fejervarya } \\
\text { keralensis, Fejervarya limnocharis }\end{array}$ \\
\hline Parambikulam WLS & Euphlyctis cyanophlyctis / Nyctibatrachus major & Philautus leucorhinus & Fejervarya keralensis \\
\hline Peechi-Vazhani WLS & -- & -- & Fejervarya nilagirica \\
\hline Peppara WLS & $\begin{array}{l}\text { Euphlyctis hexadactylus / Euphlyctis } \\
\text { cyanophlyctis; Rhacophorus malabaricus / } \\
\text { Philautus pulcherrimus }\end{array}$ & -- & Rana temporalis \\
\hline Periyar WLS & $\begin{array}{l}\text { Rana curtipes / Fejervarya limnocharis; } \\
\text { Euphlyctis cyanophlyctis / Nyctibatrachus major }\end{array}$ & -- & Rana temporalis \\
\hline Shenduruni WLS & -- & Fejervarya limnocharis & Fejervarya keralensis \\
\hline Silent Valley NP & Nyctibatrachus major / N. aliciae & Philautus nasutus / P. signatus & Rana temporalis \\
\hline Thattekkad BS & $\begin{array}{l}\text { Hoplobatrachus tigerinus / } \\
\text { Euphlyctis cyanophlyctis }\end{array}$ & -- & $\begin{array}{l}\text { Rana temporalis, Fejervarya } \\
\text { keralensis }\end{array}$ \\
\hline Wayanad WLS & Ichthyophis beddomei / Uraeotyphlus narayani & $\begin{array}{l}\text { Kaloula taprobanical } \\
\text { Rhacophorus malabaricus }\end{array}$ & Hoplobatrachus tigerinus \\
\hline
\end{tabular}


exist. This may have had an influenced on the adaptations acquired by amphibians inhabiting these areas.

Niche overlap is a measure of the association of two or more species. The minimum and maximum niche overlap values are 0 and 1 respectively. A value of zero indicates no overlap and one indicates 100\% overlap (Inger \& Colwell, 1977). In the present study, the following overlaps were obtained: Philautus beddomii / P. pulcherrimus at Aralam WLS; Icthyophis beddomei / Uraeotyphlus narayani at Wayanad WLS; Nyctibatrachus major / N. aliciae at Silent Valley NP; Hoplobatrachus tigerinus / Euphlyctis cyanophlyctis at Thattekkad BS; Bufo parietalis / Indirana leptodactylus and Philautus femoralis / P. signatus at Eravikulam NP; Euphlyctis cyanophlyctis / Nyctibatrachus major at Parambikulam WLS; Rana curtipes / Fejervarya limnocharis and Euphlyctis cyanophlyctis / Nyctibatrachus major at Periyar TR; Nyctibatrachus major / N. minor at Chinnar WLS; Euphlyctis hexadactylus / E. cyanophlyctis and Rhacophorus malabaricus / Philautus pulcherrimus at Peppara WLS.

Total overlap (100\%) was not reported from Idukki, Chimmini, Peechi-Vazhani, Neyyar and Shenduruni wildlife sanctuaries, and Agasthyavanam Biological Park. It is evident from the present study that amphibian communities in the protected areas of Kerala show greater ecological similarity (greater niche overlap) among coexisting species. Such similarities are already established for amphibian communities from tropical rain forests (Inger \& Colwell, 1977). It is assumed that if overlap should be greater, more species share a given variety of resources, in the absence of compensating differences in niche breadth. Resource use by ecologically more similar pairs of species is more likely to be subject to evolutionary adjustments through the combined effects of competition and environmental fluctuations (Inger \& Colwell, 1977). However, no such conclusion is possible in the absence of earlier studies in this region.

Analysis of amphibian community structure in all the protected areas of Kerala confirms the great conservation value of amphibian communities inhabiting them, since none of the communities studied has shown the characteristic patterns of disturbance. On the contrary, species distribution in all the sites indicated the presence of highly organized natural communities. However, the number and abundance of amphibian species recorded in the present study may be greatly affected by the climatological differences experienced throughout the study period. The most significant factor may be rainfall, which triggers the level of activity of many amphibians. The results of this study have therefore been possibly influenced by the different atmospheric conditions present in the protected areas during the investigation. The results obtained may therefore reflect the presence of unsuitable weather conditions, during which many species are unavailable for investigation. In order to identify the entire assemblage of species inhabiting the region, further work should concentrate on a long-term study. This would also provide a comparison between habitat use and levels of activity over a seasonal time span.

\section{REFERENCES}

Andrews, M.I., S. George and J. Joseph (2005a). A survey of the amphibian fauna of Kerala - distribution and status. Zoos' Print Journal 20(1): 1723-1735 (plus web supplement).

Andrews, M.I., S. George and J. Joseph (2005b). Amphibians in protected areas of Kerala. Zoos' Print Journal 20(4): 1823-1831.

Andrews, M.I., S. George and J. Joseph (In press). Community structure of amphibians at three protected areas of Kerala. Journal of the Bombay Natural History Society.

Crump, M.L. (1971). Quantitative analysis of the ecological distribution of a tropical herpetofauna. Museum Natural History, University of Kansas 3: $1-62$.

Das, I. (1996). Resource use and foraging tactics in a south Indian anuran community. Journal of South Asian Natural History 2(1): 1-30. Dash, M.C. and J.K. Mahanta (1993). Quantitative analysis of the community structure of tropical amphibian assemblages and its significance to conservation. Journal of Bioscience 18(1): 121-139.

Hager, H.A. (1998). Area sensitivity of reptiles and amphibians: are they indicator species for habitat fragmentation? Ecoscience 5(2): 139147.

Heyer, W.R., M.A. Donnelly, R.W. McDiarmid, L.C. Hayek and M.S. Fister (1994). Measuring and Monitoring Biological Diversity Methods for Amphibians. Smithsonian Institution Press, Washington D.C., $690 \mathrm{pp}$

Inger, R.F. (1969). Organization of communities of frogs along small rain forest streams in Sarawak. Journal of Animal Ecology 38: 123-148. Inger, R.F. (1980). Densities of floor dwelling frogs and lizards in lowland forests in south-east Asia and central America. American Nature 115: 761-770

Inger, R.F. and B. Greenberg (1966). Ecological and competitive relations among three species of frogs (genus: Rana). Ecology 47: 476759 .

Inger, R.F. and R.K. Colwell (1977). Organization of contiguous communities of amphibians and reptiles in Thailand. Ecological Monograph 47: 229-253.

Inger, R.F., H.B. Shaffer, M. Koshy and R. Bakde (1987). Ecological structure of a herpetological assemblage in South India. Amphibia Reptilia 8: 189-202.

Inger, R.F. and H.K. Voris (1993). A comparison of amphibian communities through time and from place to place in Bornean forests. Journal of Tropical Ecology 9: 409-433.

Krebs, C.J. (1999). Ecological Methodology, pp. 410-475. Addison Welsey Educational Publishers Inc.

Pearman, P.B. (1997). Correlates of amphibian diversity in an altered landscape of Amazonian Ecuador. Conservation Biology 11(5): 12111225 .

Raxworthy, C.J. and D.K. Attuquayefio (2000). Herpetological communities at Muni Lagoon in Ghana. Biodiversity Conservation 9: 501-510.

Vasudevan, K., A. Kumar and R. Chellam (2001). Structure and composition of rain forest floor amphibian communities in KalakadMundanthurai Tiger Reserve. Current Science 80(3): 406-412.

Zug, G.R. (1993). Herpetology: An Introductory Biology of Amphibians and Reptiles. Academic Press Inc., San Diego.

\section{ACKNOWLEDGEMENTS}

Authors are grateful to the Chief Wildlife Warden of Kerala for granting access to the protected areas, and the Wildlife Wardens of all sanctuaries for the help rendered during our field studies. Our thanks are due to the Ministry of Environment and Forests, Govt. of India, for providing financial assistance to carryout this work as a major project (No.30/11/ 98-RE) awarded to M.I.A. and S.G. J.J. thanks the Ministry for the fellowship. We also thank the Principal, Mar Thoma College, Tiruvalla for the institutional support during the tenure of the work. 